\title{
Molecular Phylogeny of the Philippine Endemic Genus Antherostele Bremek. (Rubiaceae) Inferred from ITS Data (nrDNA) and Its Conservation Status
}

\author{
Jasper John A. Obico ${ }^{1}$, Grecebio Jonathan D. Alejandro ${ }^{2}$ \\ ${ }^{1}$ Department of Biology, College of Arts and Sciences, University of the Philippines Manila, Manila, Philippines; ${ }^{2}$ College of Sci- \\ ence and Research Center for the Natural and Applied Sciences, University of Santo Tomas, Manila, Philippines. \\ Email: jjobico@post.upm.edu.ph
}

Received June $26^{\text {th }}, 2012$; revised July $25^{\text {th }}, 2012$; accepted August $10^{\text {th }}, 2012$

\begin{abstract}
Antherostele Bremek. is an understudied genus of Rubiaceae endemic to the Philippines formerly comprising four species of shrubs or small trees distributed in Luzon and Visayas. In this first molecular study of the genus, the ITS (nrDNA) was utilized to determine the monophyly of Antherostele, reconstruct its phylogeny, and resolve its placement in Rubiaceae. Furthermore, an update on the assessment of its conservation status of the included species in the genus was done. Antherostele is monophyletic and is nested within the tribe Urophylleae of subfamily Rubioideae which confirms its segregation from Urophyllum and its placement within Urophylleae as proposed by earlier authors based on morphology. However, the relationships of Urophylleae members remain unresolved. Antherostele is united by reflexed corolla, hairs on upper side of the corolla lobes and syngenesious stamens. The montane A. luzoniensis with small leaves is found to be sister to the rest of Antherostele species. Antherostele is hypothesized to originate from montane regions and diversified by forming larger leaves following dispersal to the shaded forest understory. From the five species of Antherostele currently recognized in the study, two are endangered (A. banahaensis, A. grandistipula) and three are critically endangered including a new species (A. callophylla, A. luzoniensis, A. sp. nov.) following the criteria of IUCN.
\end{abstract}

Keywords: Antherostele; Philippine Endemic; ITS; IUCN; Rubiaceae; Urophylleae

\section{Introduction}

Rubiaceae (coffee family) is the fourth largest family of angiosperms in the world with about 660 genera and 13,000 species [1]. It is predominantly woody and well represented in the tropics, usually comprising the understory of the forest. In the Philippines, Rubiaceae contains the largest number of indigenous species among families of dicotyledonous flowering plants. It is represented by about 80 genera and 550 species, which comprise $13 \%$ of the global Rubiaceae genera [2]. Despite this importance, Rubiaceae remains understudied and incompletely known especially in the tropics where most of the endemics are found [1]. In the Philippines, more than 15 genera contain endemic species [3] and at least four of these genera [Antherostele Bremek., Greeniopsis Merr., Sulitia (Merr.) Ridsdale, Villaria Rolfe] are endemic [2,4,5].

Antherostele is a widely accepted distinct genus segregated from Urophyllum Wall. by Bremekamp [6] based on morphological features such as long pedicels, domatia on the underside of leaves, corolla lobes distinctively hairy above, and fused anthers. Bremekamp [6] recognized four species of Antherostele, namely A. banahaensis (Elmer) Bremek., A. callophylla Bremek., A. grandistipula (Merr.) Bremek. and A. luzoniensis (Merr.) Bremek. Except for A. callophylla, three of the species were originally described as Urophyllum. However, the descriptions of the genus and its species provided are based solely on limited herbarium material; hence, some information, mostly on reproductive parts, are lacking. The genus has not been updated and revised since Bremekamp [6]. Recent collections of this endemic genus are wanting because herbarium specimens from both local herbaria, e.g. College of Agriculture Herbarium-University of the Philippines (CAHUP), Philippine National Herbarium (PNH), Philippine University Herbarium (PUH); and foreign herbaria e.g., Herbarium of the Arnold Arboretum (A), Conservatoire et Jardin botaniques de la Ville de Genève Herbarium $(G)$, Nationaal Herbarium Nederland (L), New York Botanical Garden Herbarium (NY), 
and United States National Herbarium (US), are scarce. Furthermore, the endemic genus Antherostele and its current placement in Rubiaceae have not been confronted by any molecular study. Its establishment as a genus separated from Urophyllum [6] and present inclusion in Urophylleae under Cinchonoideae [1,7] were based on morphology alone.

The internal transcribed spacer (ITS) is part of the transcriptional unit of the nuclear ribosomal DNA (nrDNA) [8] which consists of a repeated unit that exists as tandem repeats [9] in the plant genome. It is one of the most extensively used genetic markers in phylogenetic studies in angiosperms [8-10] and has been proven to be of utility for several reasons. The ITS is relatively small (ca. 700 base pairs) and is flanked by highly conserved genes (18S rRNA and 26S rRNA) which promotes ease in amplifying and sequencing [8]. ITS exists also as thousands of copies in most plant genomes thus making it very easy to detect [9]. These copies undergo concerted evolution through unequal crossing over and gene conversion, thereby homogenizing all the copies within the genome [8]. Moreover, forty percent of the ITS are highly conserved across all angiosperms sequenced, which accounts for its high sequence alignability. ITS is also rapidly evolving and is very useful in resolving issues in the generic and specific levels [9]. Lastly, the ITS spacers (ITS 1 and 2) have presumptive role in the maturation of nuclear ribosomal RNAs that accounts for its subjection to evolutionary constraints [8]. In Rubiaceae, several works have attested to the utility of ITS data in resolving taxonomic relationships [e.g., 11-15]. In the current study, the ITS is utilized in addressing taxonomic issues in Antherostele.

In 2007, the Department of Environment and Natural Resource released DENR Administrative Order No. 200701 [16] establishing a national list of threatened Philippine Plants and their categories. This list included all known species of Antherostele and categorized them as vulnerable. With the present study, this classification could be updated since knowledge about Antherostele is still inadequate especially its status in the wild.

With the lack of understanding of Antherostele and need for further assessment of its conservation status, the present study aims to test the monophyly of Antherostele, reconstruct the phylogeny of the genus and assess phylogenetic relationships of closely related genera within their resolved tribal position using the internal transcribed spacers (ITS) of the nuclear DNA. It also intends to reevaluate the status of Antherostele species in the wild following IUCN red list categories and criteria [17]. The present study is the first molecular work on Antherostele with an update on its conservation status.

\section{Methodology}

\subsection{Plant Collection}

Samples of Antherostele were collected between November 2008 and June 2010 from the following localities (Figure 1): LUZON: Mt. Palemlem, Ilocos Norte, Adams (A. callophylla); Mt. Banahaw, Quezon, Lucban (A. banahaensis); Mt. Mingan, Nueva Ecija, Gabaldon (A. luzoniensis); VISAYAS: Mt. Sohoton, Samar, Basey (A. grandistipula). Table 1 summarizes the number of samples per species collected including the number of herbarium specimens that are examined for conservation assessment.

Collection was done by obtaining the flowering and/or fruiting branch of the specimen. At least three branches were obtained and tagged from each of at least three individuals for every species for preservation as herbarium specimens. Each branch was inserted in a folded newspaper and placed in a polyethylene bag. Denatured alcohol was poured into the bag to preserve the plant until they were brought into the laboratory for processing. During collection, morphological features, especially ephemeral characteristics, i.e., odor, color etc., were noted. Some fruits and flowers were pickled in ethyl alcohol (1:1) for detailed studies in the laboratory. Two to three fresh leaves from each species were obtained and were placed in a $5 " \times 4$ " re-sealable polyethylene bag containing silica gel for molecular study [18].

\subsection{DNA Extraction and Amplification}

Total genomic DNA of silica-dried leaves of the Antherostele specimens was extracted using the DNeasy Plant Mini kit (Qiagen, Hilden, Germany).The ITS region,

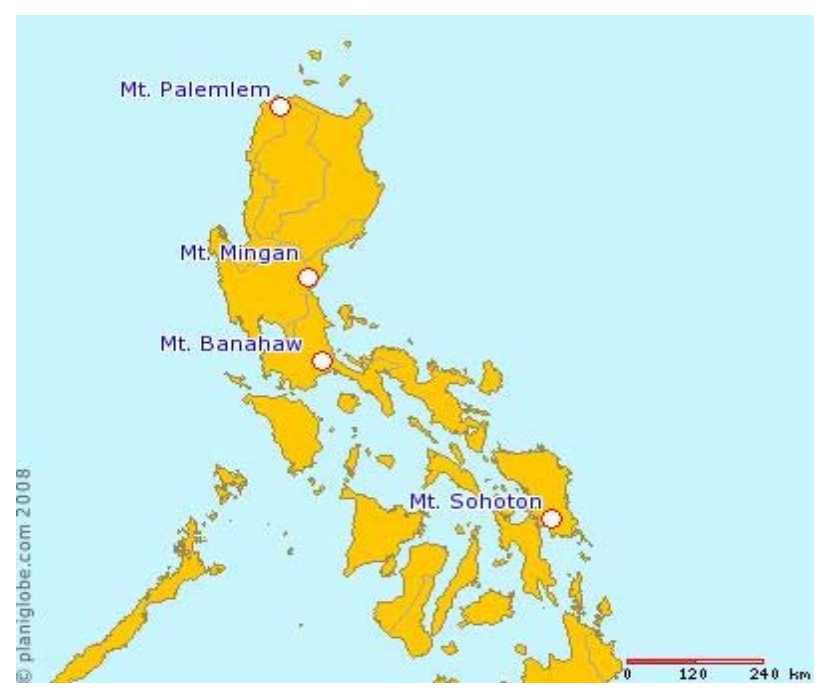

Figure 1. Map showing collection sites of Antherostele species. 
Table 1. Total number of Antherostele herbarium specimens used in the study.

\begin{tabular}{cccc}
\hline Species & $\begin{array}{c}\text { New } \\
\text { collection }\end{array}$ & $\begin{array}{c}\text { Herbarium } \\
\text { specimens }\end{array}$ & Total \\
\hline A. banahaensis & 8 & 22 & 30 \\
A. callophylla & 10 & 2 & 12 \\
A. grandistipula & 8 & 12 & 20 \\
A. luzoniensis & 6 & 2 & 8 \\
A. sp. nov. & 6 & 0 & 6 \\
Total & 38 & 38 & 76 \\
\hline
\end{tabular}

which includes ITS1, 5.8s gene, and ITS2, were amplified using primers P17F (5'- CTA CCG ATT GAA TGG TCC GGT GAA-3') and 26S-82R (5'-TCC CGG TTC GCT CGC CGT TAC TA-3') [19,20]. PCR cocktails were mixed as follows with their respective volumes: $15.3 \mu \mathrm{l}$ distilled water, $2.5 \mu \mathrm{l} 10 \times$ PCR buffer, $2.0 \mu \mathrm{l} 25$ $\mathrm{mM} \mathrm{MgCl} 2,1.5 \mu \mathrm{l} 2 \mathrm{mM}$ dNTP, $1.0 \mu \mathrm{l}$ of $10 \mu \mathrm{M}$ forward and reverse primers, respectively, $0.2 \mu \mathrm{l}$ Taq DNA polymerase and $1.5 \mu \mathrm{l}$ DNA. The total volume of the PCR reaction is $25 \mu \mathrm{l}$. The PCR reaction was run in Biometra Thermal Cycler using the following conditions: initial denaturation for $90 \mathrm{~s}$ at $97^{\circ} \mathrm{C}$, followed by 35 cycles of $20 \mathrm{~s} 97^{\circ} \mathrm{C}, 90 \mathrm{~s} 72^{\circ} \mathrm{C}, 1: 30 \mathrm{~s} 72^{\circ} \mathrm{C}$, finishing with $72^{\circ} \mathrm{C}$ for $7 \mathrm{~min}[19]$.

The amplified PCR products were then resolved in a $1 \%$ agarose gel from $5 \mu \mathrm{l}$ of the reaction mix using $1 \times$ TAE buffer [21] for verification and identification of PCR products. Subsequently the PCR products were purified using the Qia-Quick Purification kit (Qiagen) to remove excess template, primer-dimers, and oligonucleotides. The purified DNA samples, along with the primers and the documented gel, were submitted to the Department of Plant Systematics, Bayreuth University, Germany for sequencing.

\subsection{DNA Sequence Analysis}

Six ITS sequences of Antherostele are newly reported here. Their GenBank accession numbers and voucher information are listed in Table 2. Aside from the Antherostele ITS data, 52 ITS sequences from Luculia grandifolia Ghose, L. gratissima (Wall.) Sweet, and several accessions under Rubioideae including Colletoecema dewevrei (De Wild.) E.M.A. Petit and representatives from Urophylleae and Ophiorrhizeae [22,23] were retrieved from GenBank (http://www.ncbi.nlm.nih.gov/genbank/) and added in the analysis, giving a total of 58 ITS sequences. The genus Luculia, which has been shown to be the earliest diverging lineage in Rubiaceae [24], was used as an outgroup to root the ITS tree. The ITS sequences were edited using Bioedit v.7.0.4.1 then alignment of the sequences was performed using MacClade v. 4.0. The boundaries of the coding and spacer regions were deter-
Table 2. Voucher information of Antherostele materials used in this study.

\begin{tabular}{ccc}
\hline Species & Vouchers & $\begin{array}{c}\text { GenBank } \\
\text { Accession no. } \\
\text { ITS }\end{array}$ \\
\hline A. banahaensis & Obico 25102(USTH*) & JX401433 \\
A. callophylla & Obico 25100 (USTH) & JX401434 \\
A. grandistipula & Obico \& Alejandro 25111 (USTH) & JX401436 \\
A. luzoniensis 1 & Obico \& Ferreras 25122 (USTH) & JX401437 \\
A. luzoniensis 2 & Obico \& Ferreras 25123 (USTH) & JX401438 \\
A. sp. nov. & Obico \& Alejandro 25111 (USTH) & JX401435 \\
\hline
\end{tabular}

*University of Santo Tomas Herbarium.

mined using previously published ITS sequence data $[19,25]$. Excluding uninformative characters, a maximum parsimony analysis of ITS data was performed with PAUP* v. 4.0 [26] using heuristic search, with the MULTREES option on, tree-bisection-reconnection branch (TBR) swapping, swap on best only in effect, and 10,000 random addition sequences. Characters were treated unordered and weighed equally and gaps were treated as missing data. A strict consensus tree was computed from all the parsimonious trees generated by the heuristic search. The consistency index [CI; 27] and retention index [RI; 28] were calculated to estimate homoplasy. Bootstrap (BS) analysis [29] was also performed to determine robustness of the clades formed using 10,000 pseudoreplicates, with the MULTREES option off, TBR swapping, and five random addition sequences. The resulting bootstrap values were transferred to the supported clades in the strict consensus tree. Trees produced from parsimony analysis were viewed in TreeView v.1.6.6 [30] and were edited in Mesquite v.2.74 [31] and CorelDRAW X3. The following criteria were followed on describing the result of the bootstrap analysis: clades receiving a bootstrap support of $50 \%-69 \%$ : weakly supported; $70 \%-85 \%$ : moderately supported; and $86 \%-100 \%$ : strongly supported [19].

\subsection{Conservation Status Assessment}

The status in the wild of the species of Antherostele was evaluated using applicable criteria provided by IUCN version 3.1 [17]. Estimation of subpopulation involved direct observation of the individual species in the study site. The area of occupancy was based on the information provided by herbarium collections (A, CAHUP, G, HUH, $\mathrm{K}, \mathrm{L}, \mathrm{NY}, \mathrm{PNH}, \mathrm{PUH}, \mathrm{US})$. Current threats and imminent dangers to the survival species were also noted. Furthermore, the quality of the habitat was also generally assessed.

\section{Results and Discussion}

\subsection{DNA Sequence Characteristics}

The length of ITS sequences from all taxa varied from 
430 base pairs (bp) in Urophyllum blumeanum Hook.f. to 617 bp in A. banahaensis and A. callophylla (Table 3). Overall, ITS-1 is longer than ITS-2 at an average of 216 and $185 \mathrm{bp}$, respectively. The $5.8 \mathrm{~S}$ rRNA gene is invariant at $164 \mathrm{bp}$. All the values fall within the range (ITS-1:187 - 298 bp, ITS-2: 187 - 252 bp, 5.8s gene: 163 164) reported by Baldwin et al. [25] for most angiosperms.

The total $\mathrm{G}+\mathrm{C}$ percentage of the entire ITS region varied from 53.8\% in Xanthophytum borneense (Valeton) Axelius to $62.8 \%$ in Luculia gratissima, consistent with the range of values observed for most angiosperms $(\sim 50 \%-\sim 75 \%)[25]$.

\subsection{ITS Data Analysis}

Prior to parsimony analysis, it was necessary to exclude 30 characters in ITS-1 (sites 20 - 23, 41 - 49, 58, 87, 108, $112-115,128-129,167,175,193-195$ and $236-238$ ) and 38 characters in ITS-2 (sites $419-439,471-472$, $507,522,547-551,573,593,598,603-607)$ because of alignment ambiguities. Gap coding in the aligned sequences was unnecessary, as no distinct sites of insertion-deletion events was observable. The alignment of the ITS sequences of all taxa included in the study resulted in a matrix consisting of 660 characters. Among the 660 characters, only $250(37.9 \%)$ were parsimony informative (Table 3). Of these, $130(52 \%)$ were from ITS-1, 99 (39.6\%) were from ITS-2, and 21 (8.4\%) from 5.8S rRNA gene. Apparently, ITS-1 provided the greatest number of phylogenetically informative sites and $5.8 \mathrm{~S}$ rRNA gene showed the least as expected. The maximum parsimony (MP) analysis of the ITS data generated 2023 equally parsimonious trees, the strict consensus tree is shown in Figure 1 requiring 894 evolutionary steps with CI of 0.50 and RI of 0.66 .

Antherostele is monophyletic and forms a well-resolved clade (BS $=100 \%$ ). This supports the segregation of Antherostele from Urophyllum as proposed by Bremekamp [6]. Antherostele is characterized by its reflexed corolla, hairs on the corolla lobes and united anthers (Figure 2). The present analysis also confirms the placement of Antherostele in Urophylleae ( $\mathrm{BS}=74 \%$ ) which corroborates Robbrecht [1]. The present study is the first mo-

Table 3. Summary of variation within the ITS region among taxa.

\begin{tabular}{ccccc}
\hline Region & $\begin{array}{c}\text { Length } \\
(\mathrm{bp})\end{array}$ & $\begin{array}{c}\mathrm{G}+\mathrm{C} \text { content } \\
(\%)\end{array}$ & $\begin{array}{c}\text { Number of } \\
\text { parsimony } \\
\text { informative sites }\end{array}$ & $\begin{array}{c}\text { Parsimony } \\
\text { informative } \\
\text { sites (\%) }\end{array}$ \\
\hline ITS-1 & $207-234$ & $52.1-64.8$ & 130 & 52.0 \\
5.8 s gene & 164 & $51.2-56.1$ & 21 & 8.4 \\
ITS-2 & $184-236$ & $54.2-67.6$ & 99 & 39.6 \\
Entire region & $430-617$ & $53.8-62.8$ & 250 & 37.9 \\
\hline
\end{tabular}

lecular work that confirms monophyly of Antherostele and its placement within the said tribe. However, the sister group of Antherostele within Urophylleae cannot be determined in the current study as relationships within Urophylleae are not completely resolved using the present data (Figure 2).

\subsection{Phylogeny of Antherostele}

The Antherostele clade is well-resolved and shows A. luzoniensis as sister to the rest of the Antherostele (Figure 2). Antherostele luzoniensis is separated from the rest by thriving in cool montane forests located in high elevations (1500 - 1700 masl) and has relatively smaller leaves as opposed to the remaining Antherostele species which prefers humid forest at low to medium elevation (300 1000 masl) and has larger leaves. It is hypothesized that Antherostele started as a montane species and diversified following dispersal down the shaded forest understory. The current study estimates that from its small leaves, Antherostele started adapting by forming larger leaves to compensate for the reduced illumination below the forest canopy. Furthermore, ITS data suggests that Antherostele sp.nov. (Obico and Alejandro, submitted) is the sister group of the remaining understory species followed by $A$. grandistipula. Antherostele sp.nov. is notable for it is found within the geographic range of A. grandistipula, particularly in Samar. There was no evidence from morphology that these two species form natural hybrids, as both are distinct from each other. This morphological distinction of both species, while being found in similar locality, may be attributed to sympatric speciation probably caused by niche differentiation. Antherostele grandistipula seems to prefer areas along streams while Antherostele sp.nov. on the interior of the forest. However, evidences at hand appear insufficient as additional collections and field observations of $A$. sp. nov. are needed to verify this statement. Antherostele sp.nov. seems to be rare in the collection site. Antherostele banahaensis (Figure 3) and A. callophylla form a pair with a strong support $(\mathrm{BS}=83 \%)$. This indicates a close relationship between them. The two species are almost similar morphologically but can somehow be distinguished initially by longitudinal slits on branches, leaves, stipules, puberulence and other small flower details. However, these differences tend to overlap or not consistent in all specimens studied which may be due to differences in local environmental conditions and are thus not helpful distinguishing characters. A question on their distinction which could lead to their possible conspecificity could be raised. A need for revision of the genus and additional molecular study are recommended to address this concern. 


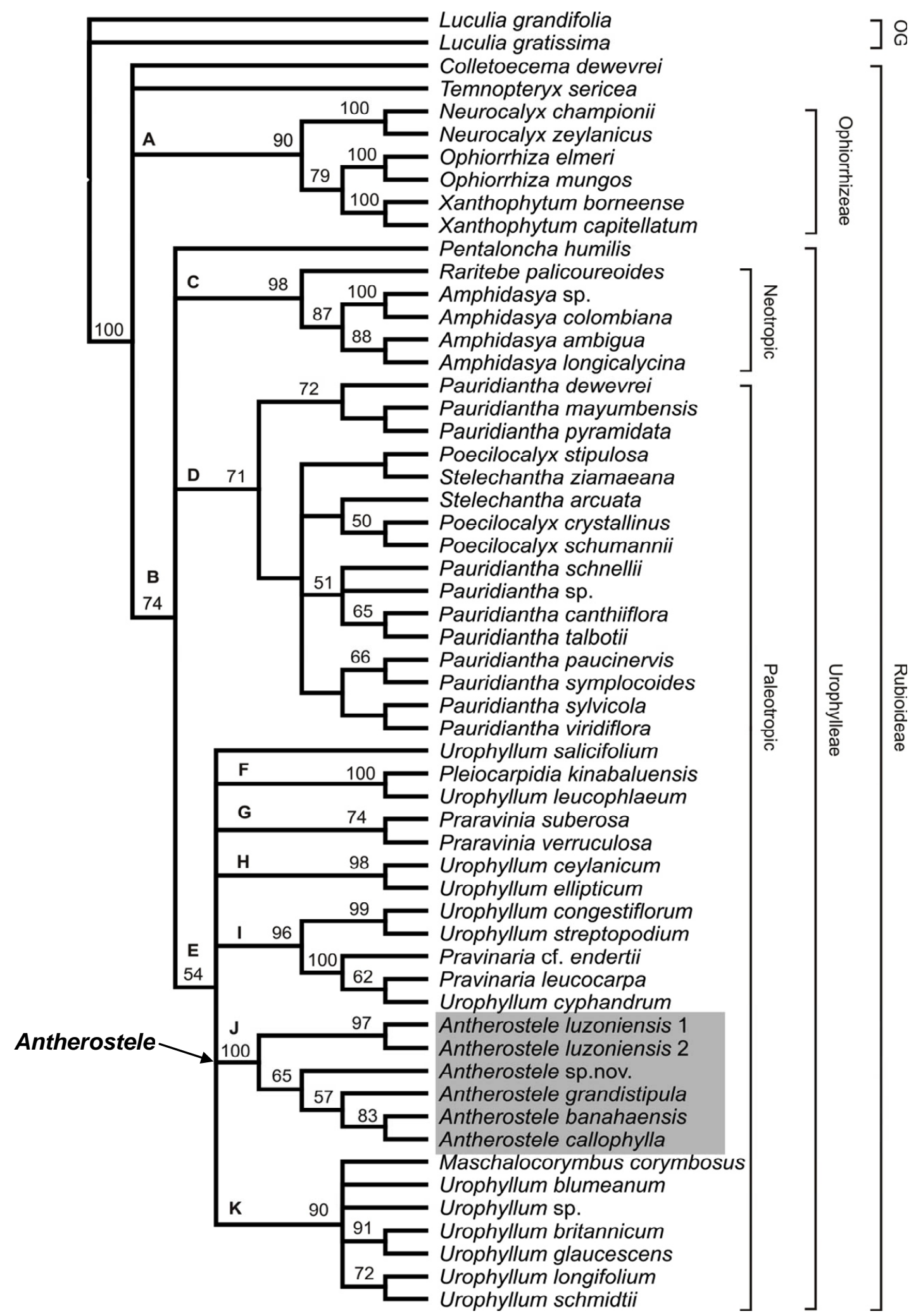

Figure 2. Strict consensus tree derived from 2023 equally parsimonious trees based on parsimony analysis of ITS sequence data. Numbers above nodes are bootstrap support values more than $50 \%$. The letters at the nodes refer to clades discussed in the text. OG refers to outgroup taxa. Clades are indicated by their respective bracket labels. Antherostele species are highlighted. 


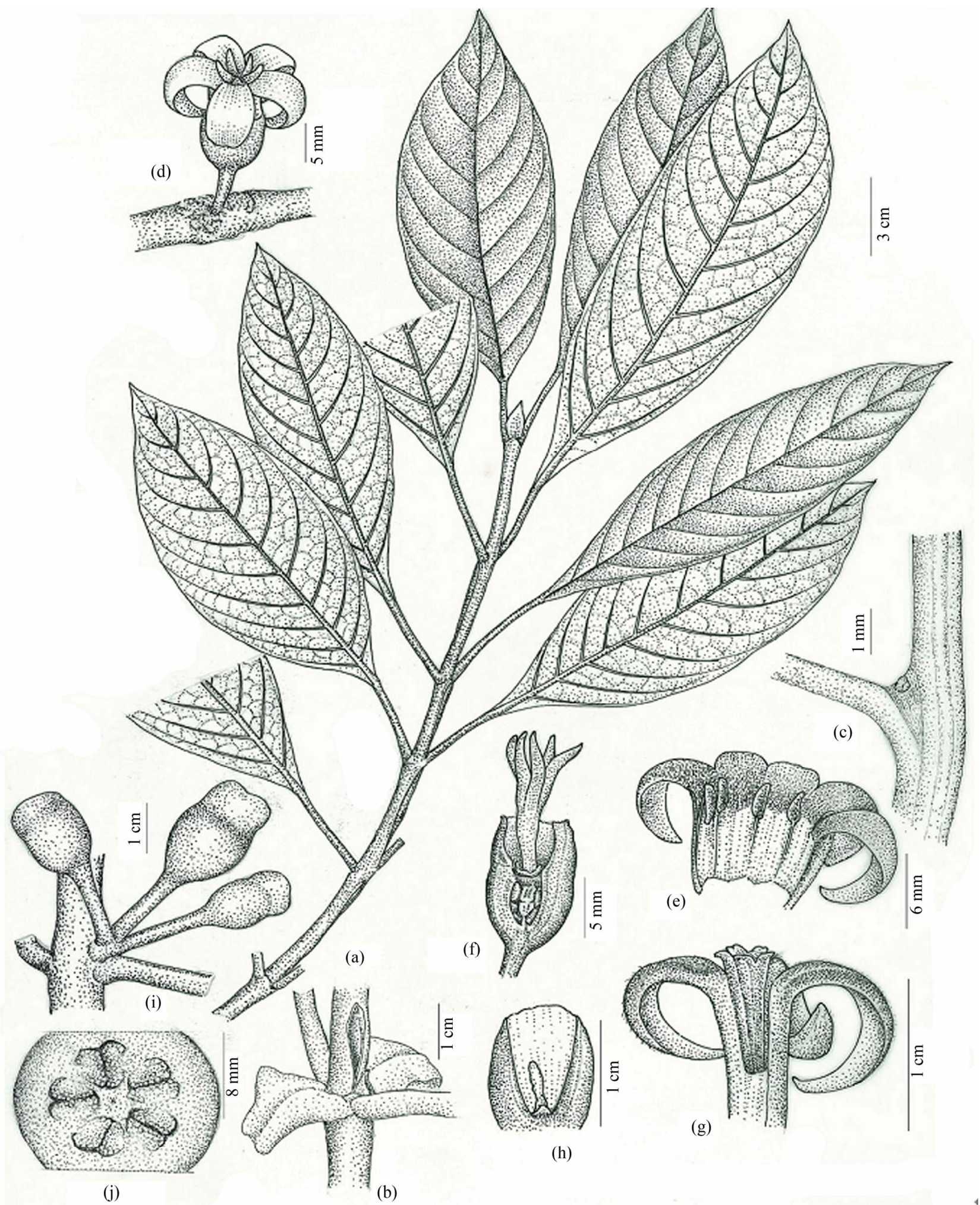

Figure 3. Antherostele banahaensis (Elmer) Bremek. (a) Leafy branch; (b) Portion of the stem with longitudinal slit and recurved stipules; (c) Axil of leaf veins with domatium; (d) Pistillate flower; (e) Corolla of pistillate flower opened to show staminodes; (f) Pistillate flower in longitudinal section without corolla; (g) Corolla of staminate flower cut open vertically to show syngenesious stamens; (h) Staminate flower in longitudinal section without corolla; (i) Immature fruits; (j) Fruit in cross section. Illustration by Nemensio B. Diego Jr. 


\subsection{Conservation Status of Antherostele Species}

Based on extensive fieldwork and examination of several herbarium specimens, an assessment of the status in the wild of the species of Antherostele was done following the criteria of IUCN [17]. This is an update from the present status of Antherostele based on DENR DAO 2007-01 [16].

1) Antherostele banahaensis (Elmer) Bremek.: This species is a Luzon endemic and is found in Cagayan, Isabela, Rizal, Laguna, Quezon, and Sorsogon provinces. It prefers low to medium altitude (300 - 830 masl), and habituates dipterocarp and mossy forest along gullies, creeks or streams with clay-loam soils. IUCN Red List Category: Endangered (EN; C2ai)-Population size estimated to number fewer than 2500 mature individuals. Continuing decline is projected and no subpopulation is estimated to contain more than 250 mature plants. All habitats of $A$. banahaensis are threatened by anthropogenic activities.

2) Antherostele callophylla Bremek.: This is another Luzon endemic and is known only from one locality, Mt. Palemlem in Ilocos Norte. It prefers medium altitude (500 - 700 masl) in dipterocarp forest along the stream with clay-loam soils. IUCN Red List Category: Critically Endangered (CR; B2ab) - the area of occupancy is estimated to be less than $10 \mathrm{~km}^{2}$, and is known to exist at only a single location. Continuing decline is projected in the area of occupancy and quality of habitat as logging activities by the indigents in the habitat of this species are beginning to take place.

3) Antherostele grandistipula (Merr.) Bremek.: This species is found in the eastern side (Camarines Sur, Catanduanes, Samar, Leyte) of the Philippine Archipelago except for one specimen in Mindoro. This species prefers river or creek bank in forest around 175 - $765 \mathrm{~m}$ asl with clay-loam soils. IUCN Red List Category: Endangered (EN; C2ai) - population size is estimated to number fewer than 2500 mature individuals. A continuing decline is projected and no subpopulation is estimated to contain more than 250 mature or even more than 50. Most areas occupied by A. grandistipula are fragmented forests caused by logging or mining activities before.

4) Antherostele luzoniensis (Merr.) Bremek. This species is endemic to Luzon and can be found in the provinces of Isabela, Nueva Ecija, and Aurora. It prefers montane forest along the ridge or slopes at around 1554 1657 masl with clay-loam soils. IUCN Red List Category: Critically Endangered (CR; C2ai) - population size is estimated to number fewer than 2500 mature individuals and a continuing decline in the number of mature individuals is projected and no subpopulation is estimated to contain more than 250 mature individuals.

5) Antherostele sp. nov. This new species is found in the forest understory of Samar and Mindoro at around 100 - 300 masl, near river banks or steep valley slopes with clay-loam soils. The species appears to be rare in the wild. IUCN Red List Category: Critically Endangered (CR; C2ai) - population size is estimated to number fewer than 2500 mature individuals and a continuing decline in the number of mature individuals is projected and no subpopulation is estimated to contain more than 250 mature individuals. The habitat of this species is threatened by human land use.

Antherostele can only be found in the Philippines and all the included species are threatened in the wild. Moreover, three species of Antherostele (A. callophylla, A. luzoniensis and $A$. sp.nov.) have restricted distribution and can be considered rare based on field observation. Aggravating further the situation is the dioecy of these species which could be a disadvantage for them. The depletion or complete lost of one member of the sex due to habitat loss could lower the species reproductive capability thus reducing progenies in the future generations. All of the aforementioned obviously connote an imperative call on protecting these species. Creation of sustainable conservation efforts for all species should be taken seriously.

\subsection{Future Studies}

To date, there has never been any attempt to study the presence of important compounds on Antherostele, as this genus has been poorly known and its endemic range limits its accessibility. Ethnobotanical accounts on Antherostele are also lacking. Systematics has a predictive value especially with regard to the discovery of bioactive or industrially important compounds on related taxa. Based on its present placement in Rubiaceae, subfamily Rubioideae [22], Antherostele can be a potential source of anthraquinones, an organic compound which has many industrial and medicinal applications.

Furthermore, Jansen et al. [32] reported aluminum accumulation in Antherostele. Being a strong aluminum accumulator, Antherostele is a promising plant for rehabilitating soils with high levels of aluminum which is one of the main players in limiting crop productivity on acidic soils. This aspect could be explored more thoroughly in future undertakings.

\section{Acknowledgements}

The authors wish to thank Philippine Council for Agriculture, Forestry and Natural Resources Research and Development; Commission on Higher Education; Research Center for the Natural and Applied Sciences of the University of Santo Tomas, Manila, Philippines; the Department of Plant Systematics, University of Bayreuth, 
Germany; and the Alexander von Humboldt Foundation.

\section{REFERENCES}

[1] E. Robbrecht, “Tropical Woody Rubiaceae," Opera Botanica Belgica, Vol. 1, 1988, pp. 1-271

[2] G. D. Alejandro and S. Liede, "The Philippine Rubiaceae Genera: Updated Synopsis in INTKEY Databases of the DELTA System,” Blumea, Vol. 48, 2003, pp. 261-277.

[3] G. D. Alejandro, "Review: The Current Status of the Philippine Rubiaceae," Philippine Journal of Systematic Biology, Vol. 1, No. 1, 2007, pp. 47-60.

[4] G. D. Alejandro, U. Meve, M. Uy, A. Mouly, M. Thiv, and S. Liede-Schumann, "Molecular Support of the Classification of Greeniopsis Merr. in Aleisanthieae (Rubiaceae) with a Revision of the Genus," Taxon, Vol. 59, No. 5, 2010, pp. 1547-1564.

[5] G. D. Alejandro, U. Meve, A. Mouly, M. Thiv and S. Liede-Schumann, "Molecular Phylogeny and Taxonomic Revision of the Philippine Endemic Villaria Rolfe (Rubiaceae)," Plant Systematics \& Evolution, Vol. 296, No. 1-2, 2011, pp. 1-20. doi:10.1007/s00606-011-0472-9

[6] C. E. B. Bremekamp, "Antherostele, Genus Novum Rubiacerum Urophyllo Affine," Journal of Arnold Arboretum, Vol. 21, No. 1, 1940, pp. 25-31.

[7] E. Robbrecht, "Advances in Rubiaceae Macrosystematics," Opera Botanica Belgica, Vol. 6, 1993, pp. 7-29.

[8] B. G. Baldwin, M. J. Sanderson, J. M. Porter, M. F. Wojchiechowski, C. S. Campbell and M. J. Donoghue, "The ITS Region of Nuclear Ribosomal DNA: A Valuable Source of Evidence on Angiosperm Phylogency," Annals of the Missouri Botanical Garden, Vol. 82, No. 2, 1995, pp. 247-277. doi:10.2307/2399880

[9] D. E. Soltis, P. S. Soltis and J. J. Doyle, "Molecular Systematics of Plants II: DNA Sequencing," Kluwer Academic Publishers, Boston, 1998.

[10] I. Alvarez and J. F. Wendel, "Ribosomal ITS Sequences and Plant Phylogenetic Inference," Molecular Phylogenetics and Evolution, Vol. 29, No. 3, 2003, pp. 417-434. doi:10.1016/S1055-7903(03)00208-2

[11] K. Andreasen, B. G. Baldwin and B. Bremer, "Phylogenetic Utility of the Nuclear rDNA ITS Region in Submfamily Ixoroideae (Rubiaceae): Comparisons with cpDNA rbcL Sequence Data," Plant Systematics \& Evolution, Vol. 217, No. 1-2, 1998, pp. 119-135. doi:10.1007/BF00984925

[12] S. G. Razafimandimbision and B. Bremer, "Phylogeny and Classification of Naucleae s.l. (Rubiaceae) Inferred from Molecular (ITS, rbcL, and trnT-F) and Morphological Data," American Journal of Botany, Vol. 89, No. 7, 2002, pp. 1027-1041. doi:10.3732/ajb.89.7.1027

[13] G. D. Alejandro, S. G. Razafimandimbison and S. LiedeSchumann, "Polyphyly of Mussaenda Inferred from ITS and trnt-T Data and Its Implication for Generic Limits in Mussaendeae (Rubiaceae)," American Journal of Botany, Vol. 92, No. 3, 2005, pp. 544-557.

doi:10.3732/ajb.92.3.544
[14] F. Achille, T. J. Motley, P. P. Lowry and J. Jeremie, "Polyphyly in Guettarda L. (Rubiaceae, Guettardeae) Based on nrDNA ITS Sequence Data," Annals of the Missouri Botanical Garden, Vol. 93, No. 1, 2006, pp. 103-121. doi:10.3417/0026-6493(2006)93[103:PIGLRG]2.0.CO;2

[15] J. H. E. Rova, P. G. Delprete and B. Bremer, "The Rondeletia Complex (Rubiaceae): An Attempt to Use ITS, rps1, and trnL-F Sequence Data to Delimit Guettardeae, Rondeletieae, and Sections within Rondeletia," Annals of the Missouri Botanical Garden, Vol. 96, No. 1, pp. 182-193. doi: $10.3417 / 2006179$

[16] Department of Environment and Natural Resources, "Establishing the National List of Threatened Philippine Plants and Their Categories, and the List of Other Wildlife Species," DENR Administrative Order No. 2007-01, 2007.

[17] International Union for Conservation of Nature, "2001 Categories and Criteria (version 3.1)," IUCN, Gland, Switzerland, 2001.

http://www.redlist.org/info/categories_criteria2001.html

[18] M. W. Chase and H. H. Hills, "Silica Gel: An Ideal Material for Preservation of Leaf Samples for DNA Studies," Taxon, Vol. 40, No. 2, 1991, pp. 215-220. doi: $10.2307 / 1222975$

[19] G. D. Alejandro, S. G. Razafimandimbison and S. L. Schumann, "Polyphyly of Mussaenda Inferred from ITS and trnt-T data and Its Implication for Generic Limits in Mussaendeae (Rubiaceae)," American Journal of Botany, Vol. 92, No. 3, 2005, pp. 544-557. doi:10.3732/ajb.92.3.544

[20] M. Popp, and B. Oxelman, "Inferring the History of the Polyploidy in Silene aegaea (Caryophyllaceae) Using Plastid and Homoeologous Nuclear DNA Sequences," Molecular Phylogenetics and Evolution, Vol. 20, No. 2, 2001, pp. 474-481. doi:10.1006/mpev.2001.0977

[21] B. G. Baldwin, "Phylogenetic Utility of the Internal Transcribed Spacers of Nuclear Ribosomal DNA in Plants: An Example from the Compositae," Molecular Phylogenetics and Evolution, Vol. 1, No. 1, 1992, pp. 3-16. doi:10.1016/1055-7903(92)90030-K

[22] E. Robbrecht and J. Manen, "The Major Evolutionary Lineages of the Coffee Family (Rubiaceae, Angiosperms). Combined Analysis (nDNA and cpDNA) to Infer the Position of Coptosapelta and Luculia, and Supertree Construction Based on $r b c L, r p s 16, \operatorname{trnL}$-trnF and atpB-rbcL Data. A New Classification in Two Subfamilies, Cinchonoideae and Rubioideae," Systematics and Geography Plants, Vol. 76, 2006, pp. 85-146.

[23] J. E. Smedmark, C. Rydin, S. G. Razafimandimbison, S. A. Khan, S. Liede-Schumann and B. Bremer, "A Phylogeny of Urophylleae (Rubiaceae) Based on rps16 Intron Data," Taxon, Vol. 57, No. 1, 2008, pp. 24-32.

[24] B. Bremer, "Phylogenetic Studies within Rubiaceae and Relationships to Other Families Based on Molecular Data," Opera Botanica Belgica, Vol. 7, 1996, pp. 33-50.

[25] B. G. Baldwin, M. J. Sanderson, J. M. Porter, M. F. Wojchiechowski, C. S. Campbell and M. J. Donoghue, "The ITS Region of Nuclear Ribosomal DNA: A Valuable 
Source of Evidence on Angiosperm Phylogeny," Annals of the Missouri Botanical Garden, Vol. 82, 1995, pp. 247-277. doi: $10.2307 / 2399880$

[26] D. L. Swofford, "Phylogenetic Analysis Using Parsimony Analysis version 4.0b," Sinauer Associates, Massachusetts, 2002.

[27] A. G. Kluge and J. S. Farris, "Quantitative Phyletics and the Evolution of Anurans," Systematic Zoology, Vol. 18, No. 1, 1969, pp. 1-32. doi:10.2307/2412407

[28] J. S. Farris, "The Retention Index and the Rescaled Consistency Index," Cladistics, Vol. 5, No. 4, 1989, pp. 417419. doi:10.1111/j.1096-0031.1989.tb00573.x

[29] J. Felsenstein, "Confidence Limits on Phylogenies: An Approach Using Bootstrap," Evolution, Vol. 39, No. 4,
1985, pp. 783-791. doi:10.2307/2408678

[30] R. D. M. Page, "TREEVIEW: An Application to Display Phylogenetic Trees on Personal Computers," Computer Applications in the Biosciences, Vol. 12, No. 4, 1996, pp. 357-358.

[31] W. P. Maddison and D. R. Maddison, "Mesquite: A Modular System for Evolutionary Analysis, version 2.74," 2001. http://mesquiteproject.org

[32] S. Jansen, S. Dessein, F. Piesschaert, E. Robbrecht and E. Smets, "Aluminum Accumulation in Leaves of Rubiaceae: Systematic and Phylogenetic Implications," Annals of Botany, Vol. 85, No. 1, 2000, pp. 91-101. doi:10.1006/anbo.1999.1000 